\title{
Study of Typography Design as Elements in Developing The Visual City Branding Identity Of Cities in Indonesia
}

\author{
Ratno Suprapto ${ }^{1}$ and Retno Purwanti ${ }^{2}$ \\ Faculty of Technology and Design, Universitas Pembangunan Jaya \\ ${ }^{1}$ ratno.suprapto@upj.ac.id, ${ }^{2}$ retno.purwanti@upj.ac.id
}

\begin{abstract}
Typography is the study of the types and characters of letters. In addition, typography is also the art of choosing and using letters that are suitable for design needs both through print and digital media. So far, we have used more letters as elements in delivering messages. However, in this study we no longer use existing letters as objects of study, but instead focus on the aspect of letters as the visual identity of a city or region. During this time in designing the visual identity of the city (City Branding), we rarely see the use of distinctive letters in accordance with regional identity. This research using method of Domain Analysis by discussing the elements contained in the logo and typographic design criteria in particular. The implication of this study is to discuss the logotype of the appearance of destination brands in DKI Jakarta and Bandung City. The logotype of the DKI Jakarta and Bandung City logos uses the same typeface, so it does not have a different uniqueness in the appearance of the logo. Building a brand image should use a unique typeface and have differentiation according to values and philosophies.
\end{abstract}

Keywords: Letters, Visual Identity, City Branding

\section{INTRODUCTION}

Nowadays, the need for visual identity is very important in the effort to build a brand / image. Tangible and intangible values become important in building a visual identity both for the needs of the company's brand, products, personal, and place. City branding and Brand destination are one of the categories in branding activities that aim to convey a message about a place intended for tourists to come to the destination. A city can be used as a brand, as written in "the principle that cities and regions can be branded "(Kemp et al., 2012, p. 508). In an effort to build and introduce a city or tourist destination, visual identity becomes very important so that the values and advantages of the place can be well informed to the target audience and potential tourists. A good visual identity will make it easier for the target audience to recognize and identify the strengths and messages delivered specifically. Research on city branding was also carried out by Irisi Kasapi and Ariana Cela who discussed 'Destination Branding: A Review of the City Branding Literature' in the Mediterranean Journal of Social Sciences (2017).

This research will focus on the original aspects and differentiation of the cities being studied, such as research conducted by Boban Melovic and Slavica Mitrovic in a journal titled 'City-Brand Building - From City Marketing to City Branding', saying that; 
"In order to become sustainable, successful destination (city) brand development must be, first of all, original and different, but convincing (based on physical and emotional characteristics of the destinations) and relevant (directed towards the consumer in an appropriate way) as well ".

Several cities and regions in Indonesia have made logos as one of the visual identities in building city branding and brand destinations. The logos displayed by several cities and regions represent the characteristics of each city and region. In the logo, there are two important elements, namely the logo mark and type logo. Almost all logo applications displayed by several cities and regions use visual elements (logo mark) and letters (logo type). The logo mark represents the characteristics of each city or region displayed in an original, unique, simple and distinctive way. Whereas the type logo displays the text of the city name and the name of the region accompanied by a slogan. From the appearance of the logos, the interesting focus is on the use of letters or fonts used in the brand names of cities and regions, the use of the letters shown are still using letters that are general or not unique. Thus, researchers will focus on the discussion of the use of letters / fonts on logos as visual identity of city branding or destination branding.

\section{METHOD}

This research analyzed using a cultural approach to the design method of Domain Analysis by discussing the elements contained in the logo and typographic design criteria in particular. After that, the results of data analysis will be described as the conclusion of the analysis (Knox and Bickerton, 2003, p. 1001).

\section{RESULT AND DISCUSSION}

In the marketing aspect, the term brand becomes one of the cornerstones in introducing strengths and brand differentiation to the target. The definition of a brand according to the American Marketing Association (1960), according to which a brand is:

"A name, term, sign, symbol, or design, or a combination of them, intended to identify the goods or services of one seller or group of sellers and to differentiate them from those of competitors" (as cited on Wood, 2000, p. 664; italics added).

Researchers collected visual data related to visual identity especially logos on several city branding logos in Indonesia. This visual logo data collection, aims to make the visual analysis of the city branding logo look more specific. The researcher analyzes the visual data of the logo by using aspects of the criteria in designing the logo. These criteria consist of; 1). Distinctiveness, 2). Legible, 3). Simple, 4). Memorable, 5). Relevance, 6). Timeless, and 7). Easy adaptable to all media. While typography will analyze aspects of readability and legibility aspects. The characteristic aspects of the cultural approach to typography will be analyzed based on the suitability of the letter character and letter characteristics.

\subsection{Analysis of the City Branding Logo and Tagline City of DKI Jakarta.}

DKI Jakarta is a big city in Indonesia which is the capital of the Republic of Indonesia. DKI Jakarta is the center of business and government in Indonesia. In addition to being a center for business and government, DKI Jakarta has a strong culture of Betawi culture which has a system of cultural values (intangible values) and cultural artifacts (tangible values). DKI Jakarta is also one of the tourist destinations that have tourism 
places that have historical values. The following is the analysis of the Jakarta City Branding logo.

\begin{tabular}{|c|c|c|c|c|c|c|c|}
\hline No & $\begin{array}{c}\text { Logo } \\
\text { Criteria } \\
\end{array}$ & $\begin{array}{c}\text { Shape/ } \\
\text { LogoMark }\end{array}$ & $\begin{array}{c}\text { Font/ } \\
\text { Logo Type }\end{array}$ & $\begin{array}{l}\text { Color } \\
\text { Logo }\end{array}$ & $\begin{array}{c}\text { Layout } \\
\text { Logo }\end{array}$ & $\begin{array}{c}\text { Composition } \\
\text { Logo } \\
\end{array}$ & $\begin{array}{c}\text { Conclu } \\
\text { sion }\end{array}$ \\
\hline 1 & $\begin{array}{c}\text { Distinctiv } \\
\text { eness }\end{array}$ & $\begin{array}{l}\text { The shape } \\
\text { of the logo } \\
\text { comes from } \\
\text { the iconic } \\
\text { national } \\
\text { monument } \\
\text { (Monas). } \\
\text { This logo is } \\
\text { very unique } \\
\text { because the } \\
\text { shape of the } \\
\text { national } \\
\text { monument } \\
\text { only exists } \\
\text { in Jakarta. }\end{array}$ & $\begin{array}{l}\text { The font used } \\
\text { is 'Indonesia'. } \\
\text { This font is } \\
\text { used by the } \\
\text { Government } \\
\text { of Indonesia } \\
\text { in the } \\
\text { 'Wonderful } \\
\text { Indonesia' } \\
\text { Brand Nation } \\
\text { tagline. } \\
\text { The font does } \\
\text { not } \\
\text { specifically } \\
\text { represent the } \\
\text { city of DKI } \\
\text { Jakarta }\end{array}$ & $\begin{array}{l}\text { This logo } \\
\text { uses } 7 \\
\text { colors. } \\
\text { Among } \\
\text { them; } \\
\text { Orange, } \\
\text { magenta, } \\
\text { purple, } \\
\text { blue, } \\
\text { green, } \\
\text { black and } \\
\text { gray. }\end{array}$ & $\begin{array}{l}\text { Horizont } \\
\text { al layout } \\
\text { style. The } \\
\text { layout } \\
\text { position } \\
\text { with this } \\
\text { style } \\
\text { focuses } \\
\text { the } \\
\text { logotype } \\
\text { on the } \\
\text { left and } \\
\text { the logo } \\
\text { mark on } \\
\text { the right. }\end{array}$ & $\begin{array}{l}\text { The } \\
\text { composition } \\
\text { of the logo } \\
\text { has a solid } \\
\text { and balanced } \\
\text { impression. }\end{array}$ & $\begin{array}{l}\text { Distinc } \\
\text { tive } \\
\text { and } \\
\text { Unique }\end{array}$ \\
\hline 2 & Legible & $\begin{array}{l}\text { The } \\
\text { logomark } \\
\text { form is } \\
\text { quite } \\
\text { legible }\end{array}$ & $\begin{array}{l}\text { This Font or } \\
\text { logotype on } \\
\text { logo is quite } \\
\text { readability } \\
\text { and legibility }\end{array}$ & $\begin{array}{l}\text { The logo } \\
\text { color is } \\
\text { quite } \\
\text { legible }\end{array}$ & $\begin{array}{l}\text { The logo } \\
\text { layout is } \\
\text { balance }\end{array}$ & $\begin{array}{l}\text { The } \\
\text { composition } \\
\text { of the logo } \\
\text { has a solid } \\
\text { and balanced } \\
\text { impression }\end{array}$ & Legible \\
\hline 3 & Simple & $\begin{array}{l}\text { The } \\
\text { logomark } \\
\text { form is } \\
\text { quite } \\
\text { simple }\end{array}$ & $\begin{array}{c}\text { Simple, } \\
\text { readability } \\
\text { and legibility }\end{array}$ & $\begin{array}{l}\text { The logo } \\
\text { color is } \\
\text { not } \\
\text { simple, } \\
\text { too much } \\
\text { color }\end{array}$ & $\begin{array}{l}\text { The logo } \\
\text { layout } \\
\text { color is } \\
\text { not } \\
\text { simple }\end{array}$ & $\begin{array}{l}\text { logo color } \\
\text { composition } \\
\text { is quite } \\
\text { complex }\end{array}$ & $\begin{array}{c}\text { Not } \\
\text { Simple }\end{array}$ \\
\hline 4 & $\begin{array}{c}\text { Memorab } \\
\text { le }\end{array}$ & $\begin{array}{l}\text { logo shape } \\
\text { is easy to } \\
\text { remember } \\
\text { or } \\
\text { memorable }\end{array}$ & $\begin{array}{l}\text { Font shape is } \\
\text { easy to } \\
\text { remember or } \\
\text { memorable }\end{array}$ & $\begin{array}{l}\text { The logo } \\
\text { color is } \\
\text { not } \\
\text { memorab } \\
\text { le }\end{array}$ & $\begin{array}{l}\text { Layout } \\
\text { logo is } \\
\text { easy to } \\
\text { remembe } \\
\text { r or } \\
\text { memorab } \\
\text { le }\end{array}$ & $\begin{array}{l}\text { composition } \\
\text { logo is easy } \\
\text { to remember } \\
\text { or memorable }\end{array}$ & $\begin{array}{c}\text { Memor } \\
\text { able }\end{array}$ \\
\hline 5 & $\begin{array}{c}\text { Relevanc } \\
\text { e }\end{array}$ & $\begin{array}{l}\text { The shape } \\
\text { of the logo } \\
\text { is very } \\
\text { relevance }\end{array}$ & $\begin{array}{l}\text { The font of } \\
\text { the logo is not } \\
\text { relevance }\end{array}$ & $\begin{array}{l}\text { The color } \\
\text { of the } \\
\text { logo is } \\
\text { not } \\
\text { relevant }\end{array}$ & $\begin{array}{l}\text { The } \\
\text { layout of } \\
\text { the logo } \\
\text { is very } \\
\text { relevant }\end{array}$ & $\begin{array}{l}\text { The } \\
\text { composition } \\
\text { of the logo is } \\
\text { very relevant }\end{array}$ & $\begin{array}{c}\text { Releva } \\
\text { nce for } \\
\text { logo } \\
\text { mark, } \\
\text { but not } \\
\text { relevan } \\
\text { ce for } \\
\text { logo } \\
\text { type }\end{array}$ \\
\hline 6 & Timeless & $\begin{array}{l}\text { The shape } \\
\text { of the logo } \\
\text { can be } \\
\text { predicted to } \\
\text { be long- } \\
\text { lived } \\
\text { (timeless) }\end{array}$ & $\begin{array}{l}\text { The logotype } \\
\text { of the logo } \\
\text { can be } \\
\text { predicted to } \\
\text { be long-lived } \\
\text { (timeless) }\end{array}$ & $\begin{array}{l}\text { The color } \\
\text { in the } \\
\text { logo can } \\
\text { be } \\
\text { predicted } \\
\text { not too } \\
\text { long- } \\
\text { lived }\end{array}$ & $\begin{array}{l}\text { The } \\
\text { layout of } \\
\text { the logo } \\
\text { can be } \\
\text { predicted } \\
\text { to be } \\
\text { long- } \\
\text { lived } \\
\text { (timeless) }\end{array}$ & $\begin{array}{l}\text { The } \\
\text { composition } \\
\text { of the logo } \\
\text { can be } \\
\text { predicted to } \\
\text { be long-lived } \\
\text { (timeless) }\end{array}$ & $\begin{array}{l}\text { Timele } \\
\text { ss }\end{array}$ \\
\hline
\end{tabular}




\begin{tabular}{|c|c|c|c|c|c|c|c|}
\hline 7 & $\begin{array}{c}\text { Adaptabl } \\
\text { e to all } \\
\text { media }\end{array}$ & $\begin{array}{l}\text { The logo } \\
\text { form is } \\
\text { easily } \\
\text { adapted and } \\
\text { implemente } \\
\mathrm{d} \text { in all } \\
\text { media }\end{array}$ & $\begin{array}{l}\text { The logotype } \\
\text { is easily } \\
\text { adapted and } \\
\text { implemented } \\
\text { in all media }\end{array}$ & $\begin{array}{l}\text { The } \\
\text { colors in } \\
\text { the logo } \\
\text { are not } \\
\text { easy to } \\
\text { adapt and } \\
\text { impleme } \\
\text { nt in all } \\
\text { media } \\
\text { because } \\
\text { there is a } \\
\text { color } \\
\text { gradation } \\
\text { at the top } \\
\text { of the } \\
\text { logo }\end{array}$ & $\begin{array}{l}\text { The } \\
\text { layout in } \\
\text { the logo } \\
\text { are not } \\
\text { easy to } \\
\text { adapt and } \\
\text { impleme } \\
\text { nt in all } \\
\text { media. }\end{array}$ & $\begin{array}{l}\text { The } \\
\text { composition } \\
\text { in the logo } \\
\text { are not easy } \\
\text { to adapt and } \\
\text { implement in } \\
\text { all media. }\end{array}$ & $\begin{array}{c}\text { Not } \\
\text { easy } \\
\text { adapta } \\
\text { ble to } \\
\text { all } \\
\text { media }\end{array}$ \\
\hline
\end{tabular}

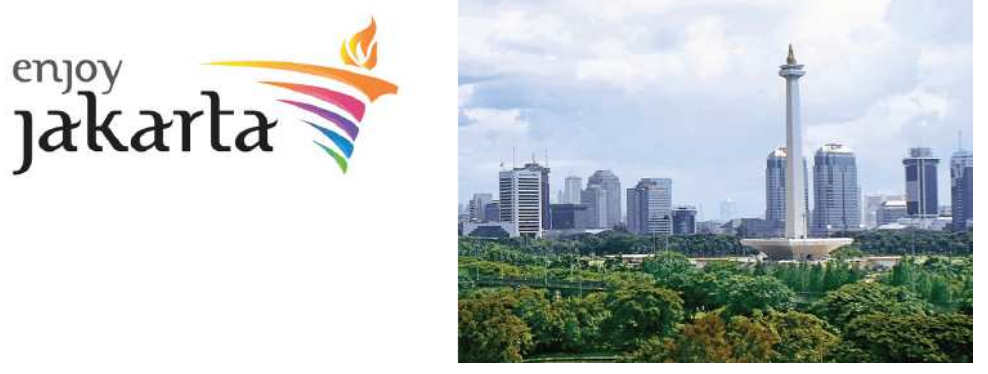

Figure 3.1. City Branding Logo of DKI Jakarta

(Source: https://saveasbrand.com/inilah-city-branding-kota-di-indonesia-untuk-pariwisata/)

Table. 3.1. City Branding of DKI Jakarta Logo Domain Analysis

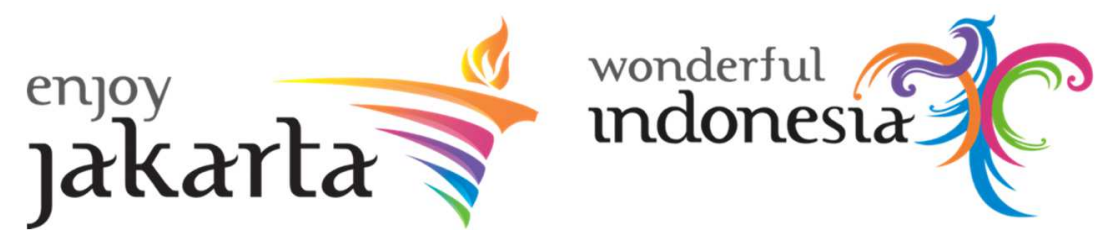

Figure3.2. Indonesia logo and DKI Jakarta logo brand destination (Source: https://jakarnaval.com/)

The 'Indonesiana' font type in the Jakarta city branding logo and the Nation Branding Indonesia logo use the same font. One side of the reasons for using the same font in the DKI Jakarta and Wonderful Indonesia logotype and tagline aims to make the tone and manner logo into a visual system. But on the other hand, because Indonesia has a variety of cultures, it will be more specific if the font is made based on the shape taken from the ornaments of the city or destination artifacts of each region. 
Table. 3.2. City Branding of DKI Jakarta Logotype and Tagline Domain Analysis

\begin{tabular}{|c|c|c|c|c|}
\hline No & Element of Logo & Readability & Legibility & Conclusion \\
\hline 1 & Logo Type & Good & Good & Good \\
\hline 2 & Tagline & Not Good & Not Good & Not Good \\
\hline
\end{tabular}

\subsection{Analysis Conclusion of the City Branding Logo and Tagline City of DKI} Jakarta.

The conclusion from the analysis of the City Branding logo from DKI Jakarta based on the results of the domain analysis can be concluded that overall the logo is quite good, but the only drawback is the element or letter elements that are not specific enough to represent the identity of the city of Jakarta. Using too much color makes the logo a little difficult to identify. While the use of letters in the logo should use letters that possess distinctive characters according to the identity of the city of Jakarta. The use of letters in the logo type and tagline logos can use a cultural approach both in form, character and letter impression. The logo type on the logo will be more relevant if it uses letters that have the basic shape drawn from the forms of ornamental cultural artifacts in DKI Jakarta. Thus, the type of letter or logo will be more relevant and more aligned with the shape of the logo mark on the appearance of the Jakarta City Branding logo. Because using the type 'Indonesiana' on the DKI Jakarta logo will give the impression that this logo is less specific, less representative of Jakarta's cultural identity. The 'Indonesiana' font has already been used by the Nation Branding Indonesia logo which has the tagline 'Wonderful Indonesia'.

\subsection{Analysis of the City Branding Logo and Tagline City of DKI Jakarta.}

The visual identity of the Bandung City Branding logo consists of the logo mark, logo type and tagline. Logo Type 'STUNNING BANDUNG' is the brand name identity that is displayed, while the tagline 'WHERE THE WONDERS OF WEST JAVA BEGINS' becomes the appeal of a unique and specific message about the advantages of Bandung. The overall appearance of the logo is quite character and strongly represents the identity of the city of Bandung visually.

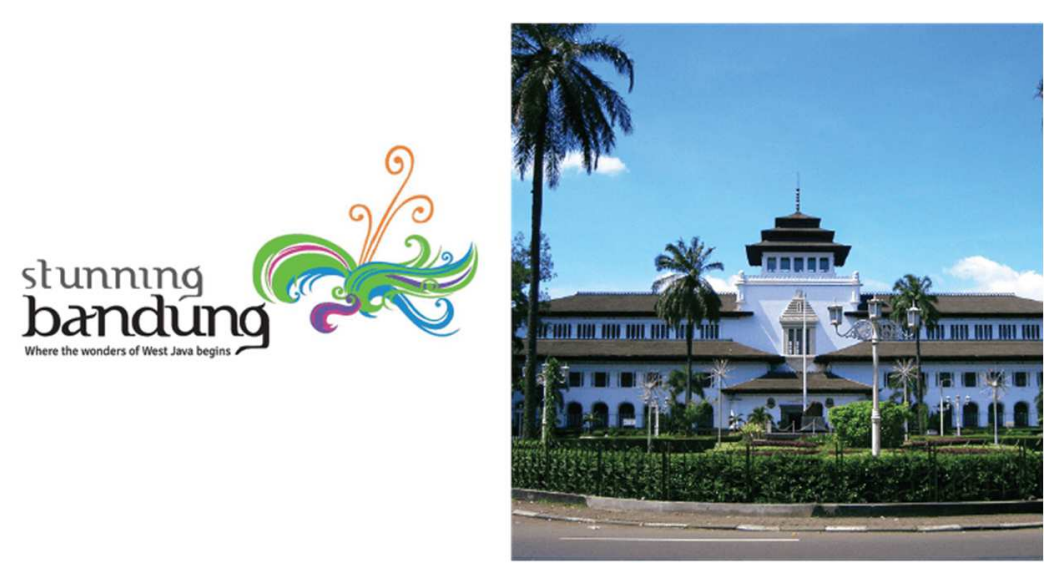

Figure 3.3. City Branding Logo of Bandung, West Java, Indonesia

(Source: https://saveasbrand.com/inilah-city-branding-kota-di-indonesia-untuk-pariwisata/)

\section{Conclusion}


The conclusion from the analysis of the City Branding logo from Bandung based on the results of the domain analysis can be concluded that overall the logo is quite good, but the only drawback is the element or letter elements that are not specific enough to represent the identity of the city of Bandung, it's similar looks like DKI Jakarta Logo. Using too much color makes the logo a little difficult to identify. While the use of letters in the logo should use letters that possess distinctive characters according to the identity of the city of Bandung. The use of letters in the logo type and tagline logos can use a cultural approach both in form, character and letter impression. The logo type on the logo will be more relevant if it uses letters that have the basic shape drawn from the forms of ornamental cultural artifacts in Bandung. Thus, the type of letter or logo will be more relevant and more aligned with the shape of the logo mark on the appearance of the Jakarta City Branding logo. Because using the type 'Indonesiana' on the Bandung logo will give the impression that this logo is less specific, less representative of Bandung's cultural identity. The 'Indonesiana' font has already been used by the Nation Branding Indonesia logo which has the tagline 'Wonderful Indonesia'. 


\section{REFERENCES}

[1]. Kemp, E., Childers, C. Y., and Williams, K. H, "Place branding: creating self-brand connections and brand advocacy, Journal of Product \& Brand Management", 2012, Vol. 21, No.7, pp. 508515.

[2]. Kasapi, Irisi. and Cela, Ariana, "Destination Branding: A Review of the City Branding Literature", Mediterranean Journal of Social Sciences, 2017, Vol. 8 No 4 July.

[3]. Wood L, "Brands and brand equity: definition and management, Journal of Management Decision", 2000, Vol.38, No. 9, pp.662 - 669.

[4]. Knox, S. and Bickerton, D, "The six conventions of corporate branding, European Journal of Marketing”, 2003, Vol. 37, No. 7/8, pp. $998-1016$.

[5]. Kavaratzis, M, "From city marketing to city branding: Towards a theoretical framework for developing city brands, Journal of Place Branding", 2004, Vol.1, No.1, pp.58 - 73.

[6]. Hill, A, "Beauty Typography: A Window Into Brand Personality". [online] Global Cosmetic Industry. Available at: http://www.gcimagazine.com/business/manufacturing/packaging/149266055.html [Accessed 2 Feb. 2018].

[7]. Dinnie, Keith, "City Branding (Theory and Chases". PALGRAVE MACMILlAN, 20011.

[8]. Cheng, K, “Designing type. New Haven”, CT: Yale University Press, 2005.

[9]. Wheeler, Alina, "Designing Brand Identity (four edition)", Published by John Wiley \& Sons, Inc., Hoboken, New Jersey, 2013.

[10]. Keller, K. L. and Lehmann, D, "Brands and Branding: Research Findings and Future Priorities", Journal of Marketing Science, 2006, Vol. 25, No. 6, pp.740-59.

[11]. Flor, M. and Flor, M, “The golden secrets of lettering”. 1st ed. Hudson, New York: Princeton Architectural Press, 2017.

[12]. Creswell, John W, "Research Design : Qualitative, Quantitative, and Mixed Methods Approaches-4th ed", SAGE Publications, California, 2014.

[13]. Carter, Rob., Day, Ben., \& Meggs, Philip, "Typographic Design: Form and Communication". John Wiley \& Sons, Inc., Hoboken, New Jersey, 2012.

[14]. Berg, P. and Sevón, G, "Food-branding places - A sensory perspective. Place Branding and Public Diplomac”y, 2014, 10(4), pp.289-304.

[15]. Hanna, S. and Rowley, J, “An analysis of terminology use in place branding. Place Branding and Public Diplomacy”, 2008, 4(1), pp.61-75.

[16]. Williams, H., Williams, R. and Omar, M, "Gastro-tourism as destination branding in emerging markets", International Journal of Leisure and Tourism Marketing, 4(1), p.1.

[17]. Kavaratzis, M., Warnaby, G. and Ashworth, G, "Rethinking place branding”. 1 st ed. Cham: Springer, 2015.

[18]. Fontsmith.com. Fonts and luxury brands: Chapter one beauty. [online] Available at: https://www.fontsmith.com/blog/2016/08/11/fonts-and-luxury-brands-chapter-one-beauty [Accessed 2 Feb. 2018].

[19]. Anholt, S, "Places - Identity, Image and Reputation”, Palgrave Macmillan, New York, NY, 2010.

[20]. Freire, J, "Managing destination brand architecture", The Case of Cascais Municipality, Place Brand and Public Diplomacy, 2016, Vol. 12, No. 78. doi:10.1057/pb.2015.23.

[21]. Greenop, K. \& Darchen, S, 'Identifying 'place' in place branding: core and periphery in Brisbane's", New World City, Geo Journal, 2016, Vol. 81, No. 3, pp. 379-394.

[22]. Hankinson, G, "The measurement of brand orientation, its performance impact and the role of leadership in the context of destination branding", Journal of Marketing Management, 2012, Vol. 28, No. 7-8, pp. 974-999.

[23]. Pereira, L.G., Correia, A. L., Schutz, R., “Destination Branding: A Critical Overview”, Journal of Quality Assurance in Hospitality \& Tourism, 2012, Vol. 13, pp. 81-102.

[24]. Pinzaru, F, "From Conjunctural urban storytelling to city branding": An Empirical Model for Bucharest, Management Research and Practice. 2012, Vol.4, No.2, pp. 33-44.

[25]. Mommas, H, "City Branding”, NAI Publishers, Rotterdam, the Netherlands, 2003.

[26]. Baker, B, "Destination Branding for Small Cities: The Essentials for Successful Place Branding”. Portland, Oregon: Creative Leap Books, 2007. 